\title{
Ketimpangan Relijiusitas dengan Perilaku: Hubungan Religiusitas dengan Perilaku Seksual Pra Nikah Remaja SMA/Sederajat di Jakarta Selatan
}

\author{
Masni Erika Firmiana*, Meithya Rose Prasetya, Rochimah Imawati \\ Program Studi Psikologi, Fakultas Psikologi dan Pendidikan, \\ Universitas Al Azhar Indonesia, Jl.Sisingamangaraja, Jakarta 12110 \\ "Penulis untuk Korespondensi: masni.erika@uai.ac.id
}

\begin{abstract}
Abstrak - Perilaku selama berpacaran yang menjurus pada perilaku seksual pranikah tidak jarang mengkhawatirkan banyak pihak. Sejumlah riset menunjukkan angka mengkuatirkan, ditambah pengalaman dokter spesialis yang menangani masalah penyakit kelamin pada remaja, dan kehamilan pada pelajar yang berasal dari sekolah berbasis agama dalam hal ini Islam. Dengan $n=60$, riset dilakukan pada siswa-siswa dari 3 jenis sekolah (umum, berbasis agama Islam, dan Madrasah. Hasilnya menunjukkan bahwa tidak ada hubungan antara religiusitas dengan perilaku berpacaran yang menjurus pada perilaku seks pra nikah. Religiusitas (pengetahuan, keyakinan, dan praktik beragama) yang tinggi ternyata tidak membuat remaja "tidak ngapangapain" dalam hubungan pacarannya. Patut dipertimbangkan penelitian lanjutan yang memperbesar jumlah responden, memasukkan variabel pengaruh media massa, peer group, serta demografi (kota besar, kota kecil, dan wilayah pedesaan).
\end{abstract}

Abstract - Boy-girl relationship or dating, occasionally leading to premarital sexual behavior, and many party worried about it. Some research showing quite apprehensive rate, in addition by medical practitioner's experiences. With $n=60$, and using quantitative methodes, this research conducted on students from different types of senior high school. Results showed that there was no relationship between religiosity and dating behaviors that lead to premarital sex. Religiosity (knowledge, beliefs, and religious practice) that did not make the teenager "don't do anything" in their relationship. We have to considering further studies to increase the number of respondents, include the variable of mass media influence, peer group, as well as demographic (large cities, small towns, and rural areas)

Keywords - Religiosity, sexual behavior, adolescence

\section{PENDAHULUAN}

Tndonesia, dengan budaya ketimuran sangat lekat dengan adat dan budayanya yang santun, dan religius (beragama). Penelitian CRCS mengungkap, $99 \%$ penduduk Indonesia memiliki agama, dan Indonesia merupakan salah satu negara dengan jumlah penduduk beragama Islam terbesar di dunia, yang membatasi kedekatan hubungan antar lawan jenis, bahkan di sekolah pun ada pemisahan antara laki-laki dan perempuan. Dalam agama Islam tidak dikenal istilah pacaran yang seperti biasanya yang berlaku pada masyarakat belakangan ini.

Meski begitu tidak hanya agama Islam yang membatasi hal tersebut. Tidak sedikit sekolah agama selain Islam yang juga menerapkan pembatasan tersebut, misalnya dengan membuat sekolah khusus putra atau putri saja, pemisahan kelas belajar antara siswa dan siswinya. Meskipun demikian, pengajaran nilai dan norma serta pembatasan tersebut, ternyata tidak mengurangi kontak antar lawan jenis di kalangan remaja.

Data dari Komnas Anak mengatakan bahwa dari tahun ke tahun angka kehamilan pranikah meningkat, dan lebih dari 93,7\% pelajar SMP dan SMU di Indonesia sudah pernah melakukan kissing, petting, oral seks (Mediana, dalam seminar, 2010). Data tersebut juga mengungkap, 62,7\% 
remaja SMP sudah tidak perawan, 21,2 \% remaja SMU pernah aborsi, dan $97 \%$ remaja pernah menonton film porno. Data yang tidak jauh berbeda juga disampaikan oleh BKKBN pada 2011. Di Jabodetabek saja, terdata $51 \%$ remaja mengaku telah melakukan hubungan seks pra nikah. Begitu juga dengan beberapa wilayah lain di Indonesia, seperti Bandung (47\%), Surabaya (54\%), dan Medan (52\%) (www.republika.co.id, www.detiknews.com).

Perilaku seks yang tidak sehat ini tentu berimplikasi pada hal lain, seperti HIV/AIDS, kehamilan yang tidak diinginkan, dan aborsi. Data dari BKKBN, berdasar penelitian di Yogyakarta ditemukan bahwa sekitar $37 \%$ dari 1.160 mahasiswa mengalami kehamilan pra nikah, estimasi jumlah kasus aborsi di Indonesia pertahun mencapai 2,4 juta jiwa, dan 800.000 di antaranya terjadi di kalangan remaja. Sementara data yang dirilis Kemenkes, pada akhir Juni 2010 terdapat 21.770 kasus AIDS dan 47.157 kasus HIV positif, persentase tertinggi pengidap usia 20-29 tahun $(48,1 \%)$, dan usia $30-39$ tahun $(30,9 \%)$.

Implikasi perilaku seksual masa pacaran (pranikah) pada remaja ini mempunyai pengaruh dampak panjang. Remaja yang paling menanggung resiko terberat adalah remaja putri. Karena jika berakibat pada kehamilan, maka pilihan yang dihadapi adalah apakah kehamilan tersebut diteruskan atau tidak. Jika diteruskan, akan ada resiko nilai dan norma sosial yang sudah dilanggar, dan pandangan miring serta penolakan masyarakat pada umumnya; seperti dikeluarkan oleh pihak sekolah meski UAN akan dilaksanakan seminggu lagi. Jika memilih untuk tidak meneruskan kehamilan, atau melakukan aborsi, akan beresiko terhadap kesehatan reproduksi remaja putri itu sendiri.

Mediana (2010, dalam seminar) mengungkap, kehamilan pada usia dini sangat berpengaruh terhadap kesehatan rahim perempuan, karena secara biologis rahim dipersiapkan untuk aktif setelah masa remaja usai. Hal ini akan berbahaya jika setelah terjadi kehamilan di usia dini tersebut dilanjutkan dengan aborsi. Selain efek jangka pendek (kematian karena perdarahan saat aborsi), efek jangka panjang adalah rusaknya rahim, yang akan mempengaruhi janin pada kehamilan berikutnya (saat si remaja ini sudah dewasa). Hal ini tentu akan berpengaruh pada kualitas kesehatannya saat hamil dan juga kesehatan bayinya nanti. Jelas bahwa tindakan tersebut merupakan perilaku yang sangat beresiko, baik secara fisik (kerusakan organ tubuh), maupun penyebaran penyakit menular dan berbahaya seperti HIV/AIDS.

Aktivitas hubungan seksual pranikah ini tentunya bertentangan dengan nilai dan norma, baik agama maupun sosial kemasyarakatan. Tidak ada satu agama pun yang memperbolehkan perilaku ini. Islam khususnya, tidak mengenal istilah pacaran. Bahkan Rasulullah melarang berkhalwat (laki dan perempuan bukan muhrim menyepi hanya berdua), karena pihak ketiga adalah syetan. Rasulullah juga menghimbau umatnya untuk menjauhi zina, antara lain dengan menjatuhkan pandangan dari lawan jenis.

Pacaran adalah salah satu bentuk pergaulan yang ditawarkan dari budaya Barat. Bentuknya bisa dimulai dari pandangan, lalu bersentuhan, berpelukan, berciuman dan seterusnya. Bentuk pacaran seperti ini jelas dilarang dalam Islam, karena sudah mendekati zina, tetapi jika hanya sampai pada saling kenal (ta'aruf) maka dibolehkan. Dewasa ini, sepertinya pacaran telah mengarah pada hal-hal yang dilarang agama atau melanggar nilai-nilai Islam, sehingga lebih besar mudharat daripada manfaat. Meskipun tidak ada penjelasan Al-Qur'an dan As-Sunnah secara eksplisit mengenai pacaran, tetapi Islam telah mengatur tatacara pergaulan dengan lawan jenis, dan melarang wanita-pria yang bukan muhrimnya untuk berduaan saja. Dengan berbagai penjelasan tersebut, maka masalah dalam penelitian ini adalah apakah ada hubungan pemahaman nilai-nilai religiusitas dan tingkah laku beragama dengan aktivitas seksual pranikah (aktivitas berpacaran) remaja khususnya SLTA di wilayah Jakarta Selatan.

Selama ini penelitian tentang perilaku beresiko pada remaja biasanya berhubungan dengan konformitas, peer pressure, dan self esteem. Hal ini dapat dilihat pada, antara lain: 1) Santor, Messervey, dan Kusumakar (2000), yang mengukur bagaimana peer pressure, popularitas di sekolah, dan konformitas dapat meramalkan performa di sekolah, sikap seksual, dan beberapa tingkah laku beresiko seperti penyalahgunaan obat-obatan dan alkohol; 2) Matthew P Martens; Jennifer C Page; Emily S Mowry; Krista M Damann; et al (2006) meneliti tentang perbedaan norma aktual dan diterima yang dianut oleh pelajar, dan pengaruhnya terhadap penyalahgunaan obat-obatan, alkohol, dan perilaku seksual. Namun penelitian ini akan membahas hubungan religiusitas dengan perilaku 
seksual (hubungan seks) pra nikah pada remaja, yang tentunya dilarang oleh nilai dan norma (terutama nilai dan norma agama).

\section{KERANGKA TEORI}

\subsection{Remaja}

Masa remaja sering disebut sebagai masa peralihan diantara masa kanak-kanak dan dewasa. Dalam masa ini anak mengalami masa pertumbuhan dan masa perkembangan, baik secara fisik maupun perkembangan psikis. Remaja (adolescence) diartikan sebagai masa perkembangan transisi antara masa anak-anak menuju masa dewasa yang mencakup perubahan biologis, kognitif, dan sosialemosional. Batasan usia remaja yang umum digunakan oleh para ahli adalah antara 12 hingga 21 tahun.

Tugas perkembangan remaja yang harus dikuasai diantaranya adalah masalah seksualitas, yaitu belajar menjalankan peran seksualitas yang diakui. Seksualitas, sebagai bagian dari permasalahan remaja berkaitan dengan semua aspek perkembangan tersebut. Maka sesungguhnya, pendidikan seksualitas pada dasarnya tidak pernah mengajarkan pada anak atau remaja tentang bagaimana cara melakukan hubungan seks, ataupun hal-hal lain yang berkesan tabu dan vulgar. Seksualitas membicarakan tentang totalitas ekspresi seseorang (dalam hal ini anak, pra remaja dan remaja) sebagai laki-laki atau perempuan, apa yang dipercayai, dipikirkan dan dirasakan, bagaimana bereaksi terhadap lingkungan, bagaimana menampilkan diri, bagaimana berbudaya dan bersosial, etika dan adab pergaulan, yang kesemuanya tersebut akan mencirikan sosok identitas remaja. Karenanya pemahaman seksualitas akan menjadikan anak dan remaja mengerti benar hal-hal yang berkaitan dengan dirinya,tubuhnya, fungsi dari bagian-bagian tubuhnya, serta bagaimana menjaga diri dari hal-hal yang tidak diperkenankan.

Ketertarikan dengan lawan jenis juga mulai muncul. Ini merupakan tugas perkembangan yang pertama berhubungan dengan seks yang harus dikuasainya. Ketika mereka secara seksual sudah matang, laki-laki maupun perempuan mengembangkan sikap yang baru pada lawan jenisnya. Kesamaan dan daya tarik merupakan alasan yang penting mengapa seorang remaja mau mengajak berpacaran atau kencan seseorang.
Hipotesa kecocokan dan validasi konseksual dapat membantu dalam hal memahami daya tarik dalam berkencan. Dengan demikian, antara remaja dan pacaran merupakan dua hal yang sulit dipisahkan. Seiring dengan pertumbuhan dan perkembangan remaja, baik secara psikologis dan sosial, remaja dituntut untuk memiliki pacar, sehingga fase ini sangat mempengaruhi perkembangan kepribadian remaja.

\subsection{Perilaku Berpacaran}

Meskipun tidak ada penjelasan Al-Qur'an dan AsSunnah secara eksplisit mengenai pacaran, tetapi Islam telah mengatur tatacara pergaulan dengan lawan jenis, dan melarang wanita-pria yang bukan muhrimnya untuk berduaan saja. Namun perkembangan sosial demografi dewasa ini, relatif cukup sulit membuat pembatasan seperti itu. Misalnya pemukiman saat ini relatif cukup padat, sehingga kalaupun remaja lawan jenis duduk berduaan, masih dapat terlihat tindakan yang mereka lakukan. Sehubungan dengan itu, maka yang diistilahkan sebagai perilaku seksual pra nikah yang dibicarakan dalam penelitian ini adalah :
a. berpegangan
b. berpelukan
c. cium pipi
d. berciuman/kissing
e. bercumbu ringan
f. bercumbu berat
g. hubungan seks sebelum waktunya

\subsection{Religiusitas}

Religiusitas adalah suatu sistem nilai keberagamaan yang menggambarkan kesatuan pandangan antara kebenaran dan keyakinan agama, penghayatan dan pemahaman terhadap ajaran agama yang terpantul ke dalam sikap dan perilaku seseorang. Adapun agama yang dimaksudkan dalam penelitian ini adalah Islam. Sebagai sebuah sistem nilai, agama (Islam) memiliki tiga dimensi yaitu: dimensi keyakinan atau aqidah; dimensi praktek ibadah atau muamalah, dan dimensi pengamalan atau akhlaq. Dalam penelitian ini akan ditelusuri bagaimana keyakinan responden (remaja) terhadap ajaran agama yang dianut, bagaimana praktek ibadah yang dilakukan oleh remaja, dan pengamalan ajaran agama. Jika remaja memiliki keyakinan terhadap suatu ajaran agama (dalam hal ini Islam), melakukan praktek ibadah sesuai keyakinan tersebut, dan mengamalkan ajaran agama dengan baik dan benar, maka seharusnya tindakan- 
tindakan/perilaku-perilaku yang dilarang dalam agama tersebut akan dihindari oleh remaja.

Religiusitas dalam kehidupan manusia memiliki fungsi individual dan fungsi sosial (Ancok, 2005). Fungsi religiusitas dalam kehidupan individu adalah sebagai suatu sistem nilai yang memuat norma-norma tertentu. Norma-norma tersebut menjadi kerangka acuan dalam bersikap dan bertingkah laku agar sejalan dengan keyakinan agama yang dianutnya. Sebagai sebuah motivasi, agama memiliki unsur ketaatan dan kesucian, sehingga memberi kemantapan batin, rasa bahagia, rasa terlindungi dan rasa puas. Sedangkan fungsi religiusitas dalam kehidupan masyarakat meliputi fungsi edukatif, penyelamat, sebagai pendamai, dan kontrol sosial. Melalui agama dapat menjamin berlangsungnya ketertiban dalam kehidupan moral dan ketertiban bersama (Jalaluddin, 2008). Berdasarkan hal ini, seharusnya dengan memiliki keyakinan terhadap suatu ajaran agama (dalam hal ini Islam), lalu melakukan praktek ibadah sesuai keyakinan tersebut, dan mengamalkan ajaran agama dengan baik dan benar, fungsi religiusitas sebagai acuan norma dapat berjalan dengan baik. Dengan kata lain, seharusnya tindakan - tindakan yang bertentangan dengan nilai dan norma agama tidak akan dilakukan/dihindari oleh remaja.

\section{METODE PENELITIAN}

Ruang lingkup dan objek penelitian ini meliputi: Wilayah penelitian dibatasi pada SLTA di Jakarta; Sasaran Penelitian adalah pelajar SLTA, baik sekolah umum, sekolah Islam, dan Madrasah; Penelitian akan mengkaji religiusitas dan perilaku seksual pra nikah pelajar

Penelitian ini merupakan penelitian penjajagan, untuk mendapat gambaran awal dari isue, untuk nanti dalam penelitian selanjutnya akan dikembangkan menjadi penelitian yang lebih mendalam dengan alat ukur yang lebih baik. Pendekatan yang digunakan dalam penelitian ini adalah kuantitatif dengan jenis penelitian survei. Penelitian survei merupakan penelitian yang menggunakan kuesioner sebagai instrumen penelitian. Penggunaan kuesioner dimaksudkan untuk mengetahui religiusitas dan perilaku seksual pra nikah para responden remaja. Alat ukur dalam penelitian ini diadaptasi dari Religiosity Measure yang disusun oleh Rohrbaur, J. dan Jessor, R. (1975), yang sebelumnya telah diuji dan terbukti reliabel.
Sampel dalam penelitian ini adalah pelajar SLTA Jakarta, yang diambil dengan cara random. Jumlah sampel yang diperoleh 60 (enam puluh) orang, yang berasal dari sekolah umum, sekolah Islam, dan Madrasah.

\section{HASIL DAN PEMBAHASAN}

\subsection{Gambaran Umum Responden Penelitian}

Berdasar data kuesioner, $\mathrm{N}=60$ orang, rentang usia 17-19 tahun $(17$ tahun $=25 \%, 18$ tahun $=70 \%$, dan 19 tahun $=5 \%$ ). Namun setelah melalui uji terhadap lembar kuesioner, dari 60 orang, hanya 59 responden yang layak untuk diuji.

Sedangkan dari sisi jenis kelamin, $\mathrm{L}=13,3 \%$, dan $\mathrm{P}$ $=86,7 \%$. Jika dilihat dari asal sekolah, $66,7 \%$ berasal dari sekolah umum, 30\% sekolah Islam, sisanya 3,3\% berasal dari Madrasah. Pada item umur pertama pacaran, 11,6\% menjawab sejak SD, $56,7 \%$ sejak SMP, $21,7 \%$ sejak SMA, sisanya $10 \%$ belum pernah pacaran.

\subsection{Religiusitas Responden}

Religiusitas terdiri dari tiga komponen, yakni pengetahuan agama, keyakinan beragama dan praktik beragama (tabel 1). Pada pengetahuan agama, responden menjawab 6 butir pertanyaan yang mencerminkan sejauh mana pengetahuan agama mereka (skor: 0: salah, 1: benar, dengan skor total: 6). Didapatkan bahwa nilai rata-rata variabel pengetahuan agama adalah: 4,47, dengan standar deviasi: 0,75. Artinya, pengetahuan agama rata-rata responden cukup tinggi. Pada variabel keyakinan beragama, responden menjawab 5 (lima) butir pertanyaan yang terkait dengan keyakinan mereka terhadap bagaimana agama berperan dalam kehidupan sehari-hari (skor : 1: keyakinan rendah, 2: keyakinan cukup rendah, 3: keyakinan sedang, 4: keyakinan cukup tinggi, 5: keyakinan tinggi, dengan skor total: 30). Hasil menunjukkan bahwa keyakinan beragama responden rata-rata (mean): 21,35. Ini dapat dimaknai bahwa responden dalam penelitian ini memiliki keyakinan beragama yang cukup tinggi. Komponen yang ketiga adalah Praktik keagamaan. Untuk mengukurnya, responden diminta menjawab 4 butir pertanyaan yang terkait dengan praktik keagamaan yang mereka lakukan sehari-hari (skor $=1$ : praktik keagamaan rendah, 2: praktik keagamaan cukup 
rendah, 3: praktik keagamaan sedang, 4: praktik keagamaan cukup tinggi, 5: praktik keagamaan tinggi, dengan skor total: 20). Hasilnya, nilai rata-rata (mean) Praktik Keagamaan responden adalah 16,87 dengan standar deviasi 2,3. Artinya, praktik keagamaan responden tergolong cukup tinggi. Jadi dari ketiga data statistik tersebut, dapat disimpulkan bahwa responden memiliki religiusitas yang cukup tinggi.

Tabel 1. Mean Komponen Religiusitas

\begin{tabular}{ccc}
\hline Komponen & Mean & Std. Deviasi \\
\hline Pengetahuan agama & 4.4746 & .75100 \\
Keyakinan beragama & 21.3500 & 2.16932 \\
Praktik keagamaan & 16.8667 & 2.31770 \\
\hline
\end{tabular}

\subsection{Perilaku berpacaran}

Untuk mengetahui perilaku berpacaran, responden diminta menjawab perilaku apa yang sering mereka lakukan saat berpacaran (Skor 0: tidak melakukan apa-apa, 1: berpegangan, berpelukan, cium pipi, 2: perilaku kategori 1, ditambah berciuman dan bercumbu ringan, 3: perilaku kategori 1,2 dan ditambah bercumbu berat dalam keadaan berpakaian dan sexual intercourse). Didapatkan bahwa nilai rata-rata perilaku berpacaran responden adalah: 1,38, dengan standar deviasi: 0,7. Ini bisa disimpulkan bahwa responden dalam penelitian ini rata-rata melakukan kontak fisik seperti berpegangan, berpelukan dan cium pipi saat berpacaran. Lebih jauh lagi, penelitian ini menemukan bahwa responden laki-laki cenderung berpacaran lebih jauh (mean: 1,75, standar deviasi: 0,89 ) dibandingkan responden perempuan (mean: 1,33, standar deviasi: 0,65 ).

\subsection{Hubungan Religiusitas dengan Perilaku Berpacaran Responden}

Setelah melihat religiusitas dari responden, kemudian dilakukan analisis untuk menjawab pertanyaan, apakah ada hubungan antara religiusitas dengan perilaku seks pra nikah. Pada bagian ini akan dianalisis hubungan pengetahuan agama dengan perilaku seks pra nikah, hubungan keyakinan beragama dengan perilaku seks pra nikah, dan praktik beragama dengan perilaku seks pra nikah.

\subsubsection{Hubungan Pengetahuan Agama (PA) dengan perilaku berpacaran.}

Pada bagian ini akan diukur bagaimana hubungan antara Pengetahuan Agama (PA) dengan perilaku berpacaran.

Tabel 2. Hubungan Pengetahuan Agama (PA) dengan perilaku berpacaran.

\section{Correlations}

\begin{tabular}{llrr}
\hline & & $\begin{array}{c}\text { Perilaku } \\
\text { Berpacaran }\end{array}$ & \multicolumn{1}{c}{ PA } \\
\hline Perilaku & Pearson & 1 & -.214 \\
Berpacaran & Correlation & & .104 \\
& Sig. (2-tailed) & 60 & 59 \\
PA & N & -.214 & 1 \\
& Pearson & .104 & \\
& Correlation & 59 & 59 \\
& Sig. (2-tailed) & & \\
& N & & \\
\hline
\end{tabular}

Berdasarkan analisis menggunakan SPSS Bivariate correlation tersebut, dengan $\mathrm{P}$ (sig 2 tailed) $>0,05$, diperoleh angka $r$ : -0,214. Ini artinya, pengetahuan agama berhubungan secara negatif dengan perilaku seksual sebesar 0,214 (korelasi sangat lemah). Sementara korelasi kedua variabel tersebut tidak signifikan karena angka signifikansi 0,104>0,05.

\subsubsection{Hubungan Keyakinan Agama (believe terhadap agama/BA) dengan perilaku berpacaran}

Pada bagian ini akan diukur bagaimana hubungan antara keyakinan (believe) terhadap agama yang dianut (Islam) dengan perilaku berpacaran

Tabel 3. Hubungan Keyakinan Agama (believe terhadap agama/BA) dengan perilaku berpacaran

Correlations

\begin{tabular}{llrr}
\hline & & \multicolumn{2}{c}{ Perilaku } \\
& & BA & Berpacaran \\
\hline BA & Pearson Correlation & 1 & .045 \\
& Sig. (2-tailed) & & .735 \\
& N & 60 & 60 \\
Perilaku & Pearson Correlation & .045 & 1 \\
Berpacaran & Sig. (2-tailed) & .735 & \\
& N & 60 & 60 \\
\hline
\end{tabular}

Dari data di atas terlihat, untuk variabel keyakinan agama, didapatkan r : 0,045. Artinya, Keyakinan agama berhubungan positif dengan perilaku seksual sebesar r: 0,045. Tetapi angka ini menunjukkan hampir tidak ada hubungannya. Ini sesuai dengan 
signifikansi korelasinya $0,0735>0,05$, yang menunjukkan bahwa korelasi kedua variabel tidak signifikan, artinya tidak ada hubungan antara believe terhadap agama dengan perilaku berpacaran.

\subsubsection{Hubungan antara praktik agama (PrA) dengan perilaku berpacaran.}

Tabel 4. Hubungan antara praktik agama (PrA) dengan perilaku berpacaran

\begin{tabular}{llrr}
\multicolumn{4}{c}{ Correlations } \\
\hline & & \multicolumn{2}{c}{ Perilaku } \\
& & \multicolumn{1}{c}{ Berpacaran } \\
\hline PRA & Pearson Correlation & 1 & -.126 \\
& Sig. (2-tailed) & & .336 \\
& $\mathrm{~N}$ & 60 & 60 \\
Perilaku & Pearson Correlation & -.126 & 1 \\
Berpacaran & Sig. (2-tailed) &.$\underline{336}$ & 60 \\
& $\mathrm{~N}$ & 60 & 60 \\
\hline
\end{tabular}

Berdasarkan tabel di atas terlihat, bahwa $r$ : $-0,126$. Artinya, Praktik agama berhubungan negatif dengan perilaku seksual sebesar r: - 0,126 (korelasi sangat lemah). Sementara korelasi pun tidak signifikan, karena didapatkan angka sig (2 tailed) sebesar 0,036>0,05, yang berarti tidak ada hubungan antara melakukan praktik ibadah agama dengan perilaku berpacaran pada responden.

Dari analisis menggunakan SPSS Bivariate correlation di atas, dengan $\mathrm{P}$ ( $\operatorname{sig} 2$ tailed) $>0,05$, ternyata tidak ada hubungan antara religiusitas (pengetahuan beragama, keyakinan beragama, dan praktik menjalankan ibadah agama) yang tinggi, dengan perilaku berpacaran. Religiusitas responden tidak membuat mereka "tidak ngapa-ngapain" selama berpacaran. Hal ini didukung oleh data dari pertanyaan terbuka, "jika bersama pacar, apa yang biasanya kamu lakukan?" 54,2 \% responden menjawab berpegangan, dan berpelukan; 35,5\% responden menjawab berpegangan, berpelukan, dan cium pipi; dan 5\% menjawab berciuman/kissing, bercumbu ringan, bercumbu berat dengan pakaian lengkap, melakukan sexual intercourse, dimana ada 2 responden yang menjawab melakukan sexual intercourse di rumah, dan di apartemen.

Melihat pergaulan anak remaja zaman sekarang, berpegangan, berpelukan, bahkan berciuman (meski di tempat umum) sangatlah lumrah terjadi, namun bagaimanapun, ajaran Islam jelas-jelas melarang hal ini. Meski agama melarang, dan mereka memiliki pengetahuan soal hal ini, ternyata tidak membuat mereka tidak melakukan hal yang dilarang agama tersebut.

\section{KESIMPULAN}

Ajaran Islam melarang hubungan lawan jenis yang terlalu dekat, dengan perintah "janganlah kamu berkhalwat...". Karena itu pemahaman agama menjadi penting, untuk membatasi perilaku. Religiusitas dalam kehidupan manusia memiliki fungsi individual dan fungsi sosial (Ancok, 2005). Fungsi religiusitas dalam kehidupan individu adalah sebagai suatu sistem nilai yang memuat norma-norma tertentu. Norma-norma tersebut menjadi kerangka acuan dalam bersikap dan bertingkah laku agar sejalan dengan keyakinan agama yang dianutnya.

Namun dalam penelitian ini terungkap, meski dengan alat ukur religiusitas yang reliable, ternyata menunjukkan tidak ada hubungan antara religiusitas yang tinggi dengan perilaku seks pra nikah pada responden, dalam hal ini remaja. Responden juga menyebutkan apa yang mereka lakukan selama berdua dengan pacar, dan sejauh mana perilaku mereka berdua. Meski yang menjawab melakukan sexual intercourse hanya 2 orang, namun responden yang lain tetap melakukan perilaku berpacaran yang berlawanan dengan norma yang ada dalam Islam, dimana "lawan jenis tidak boleh berdua saja". Perilaku berpacaran lainnya seperti berpegangan, berpelukan, cium pipi (cipika-cipiki) berciuman (kissing), bercumbu berat pun mereka lakukan, dimana semua ini juga dilarang dalam ajaran Islam.

Ada dugaan hal ini bisa terjadi karena faktor-faktor lain yang membuat perilaku seksual di kalangan remaja cenderung "biasa". Dugaan itu antara lain karena Jakarta merupakan kota besar dengan segala macam fasilitas, tekanan dari teman sebaya yang melakukan perilaku pacaran yang permisif dan kemudahan akses media, seperti internet, yang membuat remaja mudah mendapatkan konten pornografi tanpa kontrol orangtua.

\section{Saran}

Dalam pengukuran psikologi dinyatakan bahwa tidak ada alat ukur yang bebas dari bias budaya. Alat ukur religiusitas yang digunakan dalam penelitian ini merupakan adaptasi dari peneliti non muslim, dimana tidak ada pertanyaan tentang pengetahuan agama mengenai batasan kedekatan 
hubungan antar lawan jenis, meski secara umum alat ukur religiusitas ini reliable. Perlu juga dikembangkan alat ukur religiusitas khusus muslim yang dapat mencakup pengetahuan, keyakinan dan praktik keagamaan yang khas di Indonesia. Seperti diketahui, budaya-budaya lokal memberikan pengaruh yang cukup besar dalam perkembangan agama di masyarakat. Berhubung penelitian ini adalah penelitian penjajagan, maka untuk penelitian selanjutnya perlu disusun alat ukur yang lebih dalam dan tepat sasaran. Juga dengan membandingkan 2 atau 3 kelompok responden yang berbeda keyakinan, tentunya akan lebih menarik. Selain itu, melibatkan partisipan yang berasal dari pesantren mungkin dapat memberikan hasil yang berbeda. Jumlah sampel yang relatif tidak banyak belum memberikan gambaran yang menyeluruh, perlu dilakukan pengulangan dengan sampel yang jauh lebih besar. Penting kiranya mempertimbangkan variabel lain seperti efek media, peer group (karena responden adalah remaja), dan lokasi penelitian yang lebih variatif seperti kota metropolitan, kota besar dan kota kecil.

Selain itu, perlu kiranya bagi orang tua, guru, sekolah melakukan sejumlah tindakan berupa pemberian pengetahuan agama yang mengarah kepada pembatasan hubungan antar lawan jenis. Selanjutnya, demi kesehatan remaja itu sendiri, pihak sekolah (mungkin dibantu lembaga yang expert dalam melakukan pelatihan) bekerja sama dengan pihak medis, dapat memberikan pelatihan ataupun seminar yang mengajak remaja untuk "say 'no' to sex before married". Diharapkan pelatihan juga dapat mendorong assertiveness remaja terhadap pengaruh peer group, media, juga menambah keimanan remaja.

\section{DAFTAR PUSTAKA}

[1] Ancok, Djamaluddin. dan Suroso, F.N (2005), Psikologi Islami, Pustaka Pelajar. Jogjakarta

[2] Deaux, Kay ; Dane, F.C.; Wrightsman, L.S.; Sigelman, C.K (1993) Social Psychology in the '90s. 9th Edition. Brooks/Cole Publishing Company - California
[3] Hewstone, M; Stroebe, W.; Codol, JP.; Stephenson, G.M. (ed) (1988) Introduction to Social Psychology. A European Perspective. Basil Blackwell. Ltd. USA

[4] Hurlock, E.Z. (1980), Psikologi Perkembangan: Suatu Pendekatan Sepanjang Rentang Kehidupan, Erlangga. Jakarta

[5] Jalaluddin (2008), Psikologi Agama, Pustaka Pelajar. Jakarta

[6] Leonard, Kathleen Cobb dan Scott-Jones Diane . A Belief-Behavior Gap? Exploring Religiosity and Sexual Activity Among High School Seniors Journal of Adolescent Research. Tucson: Jul 2010. Vol. 25, Iss. 4; pg. 578 dari www.infotrac. galegroup.com/itweb/, diakses Oktober 2010

[7] Mediana, A. 2010. Aspek Medis Pendidikan KRR. Makalah. Seminar "Bimbingan KRR bagi Guru: Memahami Kesehatan Reproduksi sebagai Pembekalan bagi Remaja". Jakarta

[8] Matthew PM; Page, JC; Mowry, ES; Damann, KM; et al. 2006. Differences Between Actual and Perceived Student Norms: An Examination of Alcohol Use, Drug Use, And Sexual Behavior. Journal of American College Health; Mar/Apr 2006; 54, 5; ProQuest Medical Library

[9] Prasetyo. B, \& Jannah, LM. (2005). Teori dan Aplikasi Metode Penelitian Kuantitatif. Jakarta: PT. Raja Grafindo Persada.

[10] Santor, D.A ., Messervey, D., \& Kusumakar, V. (2000). Measuring Peer Pressure, Popularity, And Conformity In Adolescent Boys And Girls: Predicting School Performance, Sexual Attitudes, And Substance Abuse. Journal of Youth and Adolescence, 29(2), 163-182. Retrieved September 7, 2006, from ABI/INFORM Global database.

[11] Vanderstoep, SW. and Johnston, D.D. (2009). Research Methods for Everyday Live: Blending Qualitative and Quantitative Approaches. United States: John Wiley \& Sons, Inc

[12] www.detiknews.com. KepalaBKKBN : 51 dari 100 Remaja di Jabodetabek Sudah Tak Perawan. (diakses tanggal 1 Desember 2010)

[13] www.republika.co.id. Apa yang Mendorong Remaja Berhubungan Seks Pranikah? (diakses tanggal 1 Desember 2010) 